\title{
Performance Evaluation of Symmetrical and Asymmetrical Cascaded H Bridge Multilevel Inverter Topology
}

\author{
*Aparna Prayag ${ }^{1}$, Sanjay Bodkhe ${ }^{2}$ \\ ${ }^{I}$ Department of Electrical Engineering, G. H. Raisoni College of Engineering, CRPF Gate No.3, Hingna Road, \\ Digdoh Hills, Nagpur, Maharashtra, India \\ ${ }^{2}$ Department of Electrical Engineering, Shri Ramdeobaba College of Engineering \& Management, Ramdeo \\ Tekdi, Gittikhadan, Katol Road, Nagpur India \\ Corresponding author: *Aparna Prayag
}

\section{ABSTRACT}

This paper reviews study of symmetrical and asymmetrical cascaded H-bridge multilevel inverter. Here symmetrical, binary asymmetrical and ternary asymmetrical structure formed by cascading two H-bridge cells are compared in order to find an optimum arrangement with high quality output voltage. Performance of these structures is verified through computer simulation using MATLAB/Simulink.

Index Terms: symmetrical, asymmetrical, Cascaded H Bridge, multilevel inverter, Total harmonic distortion (THD).

\section{INTRODUCTION}

The elementary concept of multilevel inverter (MLI) is to attain higher power by using number of power switches with several low voltage dc sources. It can synthesize output voltage waveform in steps closer to sine wave and reduces total harmonic distortion. Recently multilevel inverters have been used in various industrial applications like distributed generation ,adjustable speed drives, flexible ac transmission system, HVDC, electrical vehicles etc. due to prominent advantages like high quality output voltage using low switching frequency, low harmonic contents, low electromagnetic interference, less voltage stress on power switches, more efficiency and low dv/dt stress on load [1]-[6].

Enhancement in these advantages is possible by increasing number of levels of output voltage waveform but it requires large number of switches that makes circuit complex. It also raises cost and size of the circuit.

There are three main multilevel inverter topologies-neutral point clamped (NPC) [7], flying capacitor (FC) [8] and cascaded $\mathrm{H}$ bridge (CHB). CHB has become famous because of its modular design, simple control, reliability, availability and the absence of capacitor imbalance problem [9].

In this paper we are focusing on CHB topology which is series connection of several H-Bridge cells with equal and un-equal magnitude of dc sources called as symmetrical and asymmetrical structures.

\section{CASCADED H-BRIDGE MULTILEVEL INVERTER}

The cascaded H-bridge multilevel inverter is an arrangement of several units of single-phase H-bridge power cells. The $\mathrm{H}$ bridge cells are connected in series on their ac side to attain medium voltage operation and low harmonic distortion. Each H-bridge power cell which is the building block for the cascaded H-bridge inverter is supplied by an isolated dc source on the dc side. Batteries, fuel cells or ultra-capacitors are used as isolated dc sources [10]. Fig. 1 shows single-phase structure of a cascade inverter with two $\mathrm{H}$-bridges supplied by isolated dc voltage sources. An output voltage waveform is obtained by summing the output voltage of both the cells connected in series.

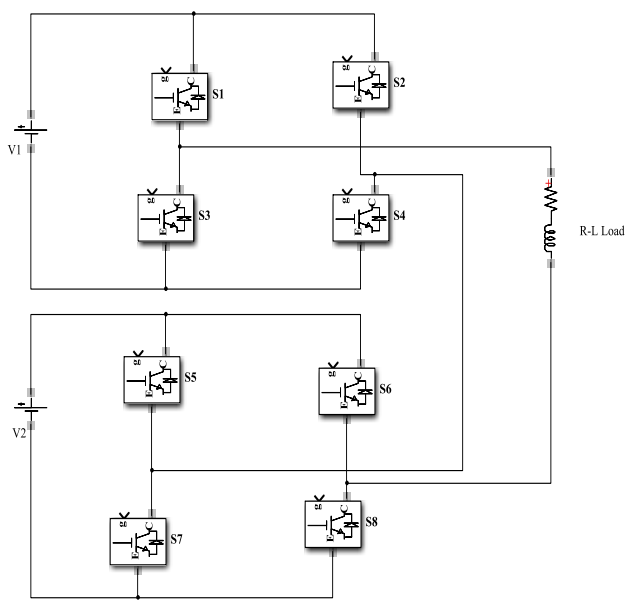

Fig. 1. Single phase structure of $\mathrm{CHB}$ inverter 
If $n$ number of cells is connected in series then total voltage across the load terminal is

$\left(V_{L}\right)_{T}=\left(V_{L}\right)_{1}+\left(V_{L}\right)_{2}+\ldots \ldots \ldots+\left(V_{L}\right)_{n}$

$\left(V_{L}\right)_{T}=\sum_{k=1}^{n}\left(V_{L}\right)$

\section{A. Symmetrical Cascaded H-Bridge Multilevel}

\section{Inverter}

If all the dc voltage sources of CHB- MLI are of equal magnitude then it is called as a symmetrical MLI. Following equations can be written for this configuration,

$V_{k}=E$

$k=1,2, \ldots \ldots . n$

Means $V_{1}=V_{2}=\ldots \ldots=V_{n}=E$

The effective number of output voltage levels $m$ in symmetric multilevel inverter is given by

$$
\begin{aligned}
& m=2 n+1 \\
& V_{M}=n E
\end{aligned}
$$

Where $n$ is number of power cells used for cascade structure and $V_{M}$ is maximum voltage generated.

For example, if $n=2$ as shown in Fig. 1 it generates 5 level voltage with maximum voltage $2 E$.

\section{B. Asymmetric Cascaded H-Bridge Multilevel Inverter}

In order to generate large number of output levels without increasing the number of cells, asymmetric multilevel inverters can be used. The magnitude of $\mathrm{dc}$ voltages sources can be selected according to a geometric progression with a factor of 2 or 3 [11].

If $\mathrm{dc}$ voltage sources are in the ratio of $1: 2$, then the inverter is known as binary asymmetric multilevel inverter. The value of each dc source can be calculated as $V_{k}=2^{(k-1)} E$

$k=1,2, \ldots \ldots . .$.

The effective number of output voltage levels $m$ and maximum voltage generated can be expressed as

$$
\begin{aligned}
& m=2^{(n+1)}-1 \\
& V_{M}=\left(2^{n}-1\right) E
\end{aligned}
$$

For two H-bridge cascaded topology this configuration generates 7 levels with maximum value $3 E$. If $\mathrm{dc}$ voltage sources are in the ratio of $1: 3$, then the inverter is known as ternary asymmetric multilevel inverter. The value of each dc source can be calculated as

$$
\begin{aligned}
& V_{k}=3^{(k-1)} E \\
& k=1,2, \ldots \ldots . . n .
\end{aligned}
$$

In this case number of voltage levels and maximum voltage generated can be calculated as

$$
\begin{aligned}
& m=3^{n} \\
& V_{M}=\frac{\left(3^{n}-1\right)}{2} E
\end{aligned}
$$

Now, this configuration generates 9 levels with maximum voltage $4 E$ for Two $H$ Bridge cascaded topology.

\section{COMPARISON BETWEEN SYMMETRIC AND ASYMMETRIC CONFIGURATION OF CASCADED H-BRIDGE MULTILEVEL INVERTER}

From above discussion it is clear that ternary asymmetrical multilevel inverter can generate more voltage levels and higher maximum output voltage with the same number of bridges as compared to symmetrical and binary asymmetrical configuration. Table I presents comparison based on the number of levels $(m)$, number of switches $(N s w)$, dc sources $(N d c)$ maximum output voltages $\left(V_{M}\right)$ and number of different voltage magnitudes $(N v)$ total voltage blocked by switches $\left(V_{b t}\right)$ when $n$ number of cells are connected in series.

Fig. 2 compares number of switches required to generate specific number of output voltage levels and Fig. 3 shows number of dc sources required for the three configurations. It is clear that ternary asymmetric configuration needs less components.

TABLE I

COMPARISON OF SYMMETRIC AND ASYMMETRIC CHB-MLI

\begin{tabular}{|c|c|c|c|}
\hline \multirow{2}{*}{ Parameters } & \multirow{2}{*}{$\begin{array}{c}\text { Symmetric } \\
\text { configuration }\end{array}$} & \multicolumn{2}{|c|}{$\begin{array}{c}\text { Asymmetric } \\
\text { configuration }\end{array}$} \\
\cline { 3 - 4 } & & Binary & Ternary \\
\hline$m$ & $2 n+1$ & $2^{(n+1)}-1$ & $3^{n}$ \\
\hline$N s w$ & $4 n$ & $4 n$ & $4 n$ \\
\hline$N d c$ & $n$ & $n$ & $n$ \\
\hline$V_{M}$ & $n E$ & $\left(2^{n}-1\right) E$ & $\frac{\left(3^{n}-1\right)}{2} E$ \\
\hline$N v$ & 1 & $n$ & $n$ \\
\hline$V_{b t}$ & $4 n E$ & $4\left(2^{n}-1\right) E$ & $2\left(3^{n}-1\right) E$ \\
\hline
\end{tabular}




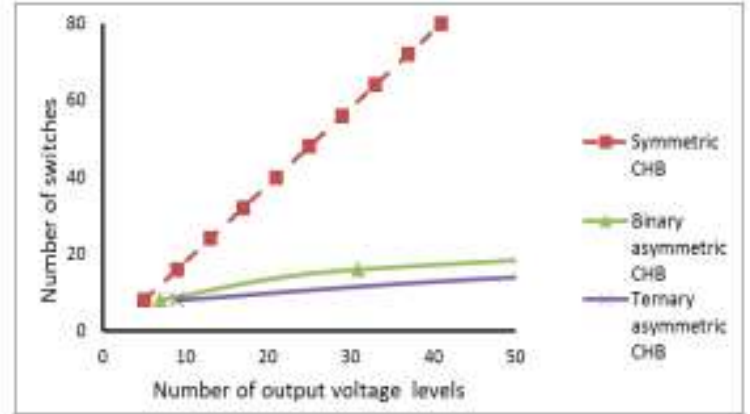

Fig. 2. Number of switches versus number of output voltage levels

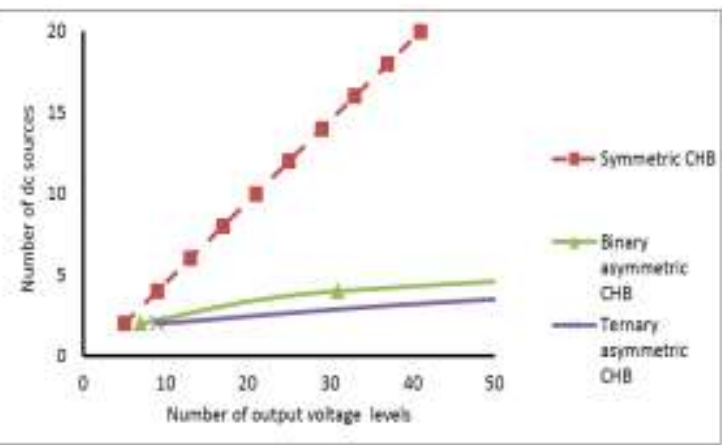

Fig. 3. Number of dc sources versus number of output voltage levels

\section{MODULATION TECHNIQUE}

The objective of modulation scheme used to control inverter is to obtain quality waveform (voltage/current) with minimum losses. Several modulation strategies have been developed for multilevel inverters. Among the commonly used modulation techniques, Pulse Width Modulation (PWM) is simple and gives high performance and therefore the most successful technique. The conventional sinusoidal PWM technique can be applied to multilevel inverter topologies by using multiple carriers. Therefore it is known as multi-carrier PWM technique. A sinusoidal reference waveform of fundamental frequency is compared with high frequency carrier waveforms having same amplitude. For $m$ level inverter $(m-1)$ carriers are required [12]. The output of comparator is high if the triangular carrier is greater than the reference signal and low otherwise. The sum of the different comparisons represents signal for output voltage level.

A multicarrier level shifted phase disposition PWM scheme is used in this paper to generate pulses for the switches of CHB-MLI.

\section{SIMULATION RESULTS}

In this paper, simulation models for five level symmetrical, seven level binary asymmetrical and nine level ternary asymmetrical CHB-MLI are developed in MATLAB/Simulink environment. For each configuration two $\mathrm{H}$-bridges are used, so that number of switches and number of dc sources in all the models are same. The switches used in the simulations are assumed to be ideal. Separate dc sources are used in the simulation studies. In practice these $\mathrm{dc}$ voltage sources are available via distributed energy resources like photovoltaic panels, fuel cells and ultra- capacitors. If the available source is an ac source then the required dc voltage sources can be obtained by using rectifiers. Simulation parameters used are given in Table II and results are shown from Fig. 4 to Fig. 9. Comparison is given in Table III.

TABLE II

SIMULATION PARAMETERS

\begin{tabular}{|l|l|l|}
\hline Description & Parameter & Value \\
\hline \multirow{2}{*}{$\begin{array}{l}\text { Symmetrical } \\
\text { inverter }\end{array}$} & $\mathrm{V}_{1}$ & 120 volts \\
\cline { 2 - 3 } & $\mathrm{V}_{2}$ & 120 volts \\
\hline $\begin{array}{l}\text { Binary } \\
\text { asymmetrical } \\
\text { inverter }\end{array}$ & $\mathrm{V}_{1}$ & 160 volts \\
\cline { 2 - 3 } $\begin{array}{l}\text { Ternary } \\
\text { asymmetrical } \\
\text { inverter }\end{array}$ & $\mathrm{V}_{2}$ & 80 volts \\
\cline { 2 - 3 } & $\mathrm{V}_{1}$ & 180 volts \\
\hline \multirow{2}{*}{ Load } & $\mathrm{V}_{2}$ & 60 volts \\
\cline { 2 - 3 } & Resistance & 100 ohms \\
\hline
\end{tabular}
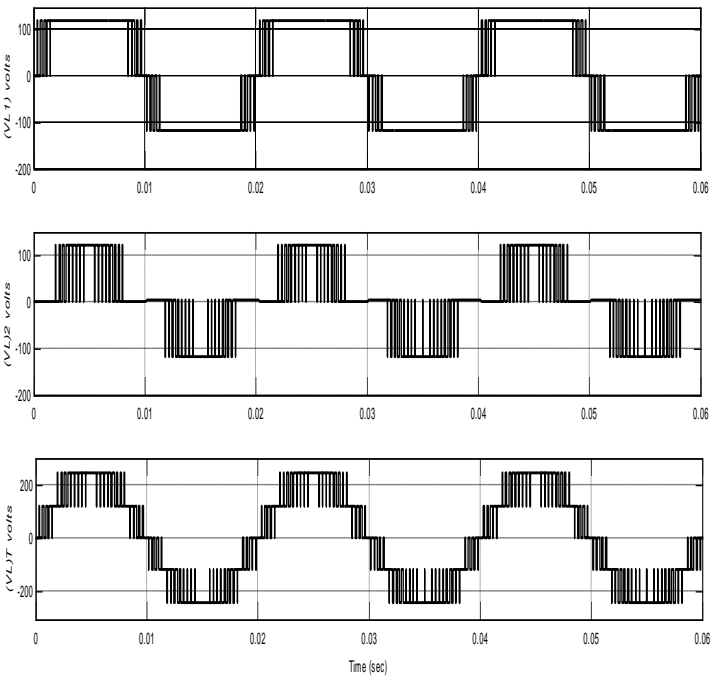

Fig.4. 5-level output voltage synthesis of symmetric CHB inverter 


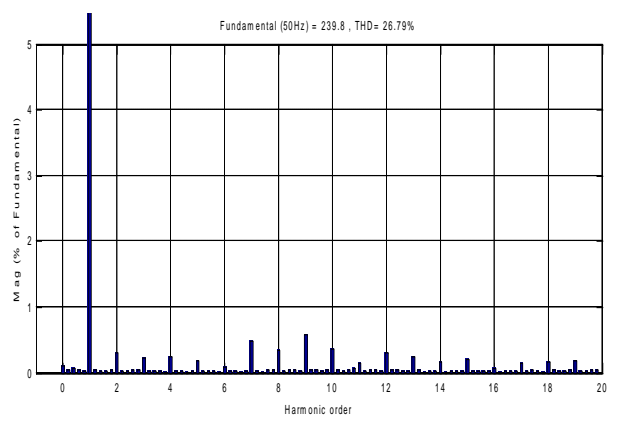

Fig.5. FFT analysis of output voltage of five level symmetric $\mathrm{CHB}$ inverter
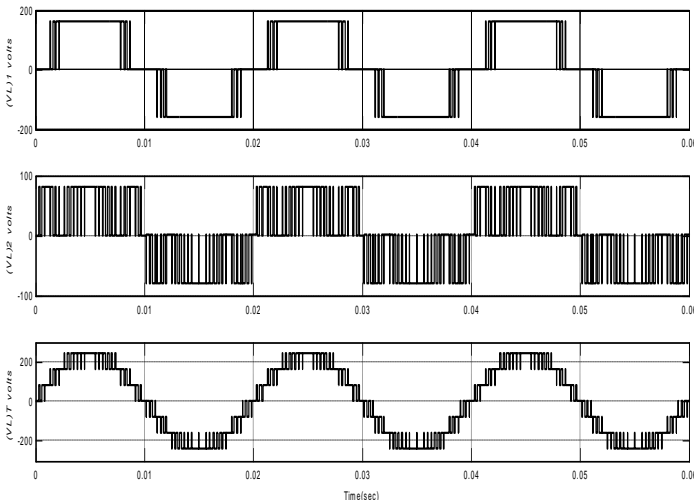

Fig.6. 7-level output voltage synthesis of binary asymmetric $\mathrm{CHB}$ inverter

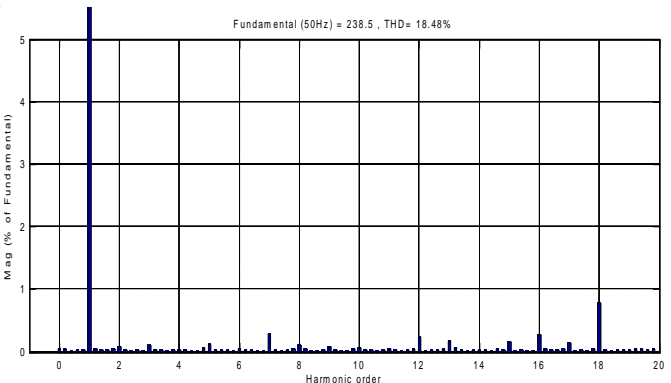

Fig.7. FFT analysis of output voltage of seven level binary asymmetric $\mathrm{CHB}$ inverter
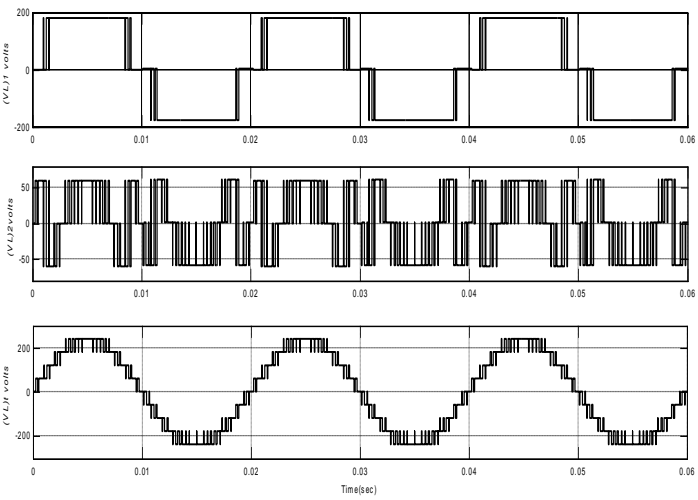

Fig.8. 9-level output voltage synthesis of ternary asymmetric $\mathrm{CHB}$ inverter

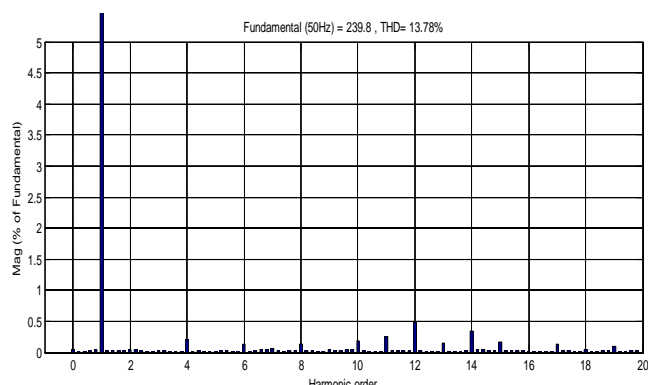

Fig.9. FFT analysis of output voltage of nine level ternary asymmetric $\mathrm{CHB}$ inverter

TABLE III

COMPARISON OF PERFORMANCE PARAMETERS OF SYMMETRICAL AND ASYMMETRICAL CHB INVERTER

\begin{tabular}{|c|c|c|c|}
\hline Parameters & $\begin{array}{c}\text { Symmetrical } \\
\text { inverter }\end{array}$ & \multicolumn{2}{|c|}{$\begin{array}{c}\text { Asymmetrical } \\
\text { inverter }\end{array}$} \\
\cline { 3 - 4 } & & Binary & Ternary \\
\hline $\begin{array}{c}\text { Number of dc } \\
\text { sources }\end{array}$ & 2 & 2 & 2 \\
\hline $\begin{array}{c}\text { Number of } \\
\text { switches }\end{array}$ & 8 & 8 & 8 \\
\hline $\begin{array}{c}\text { Fundamental } \\
\text { Frequency }\end{array}$ & $50 \mathrm{~Hz}$ & $50 \mathrm{~Hz}$ & $50 \mathrm{~Hz}$ \\
\hline $\begin{array}{c}\text { Carrier frequency } \\
\text { Voltage levels }\end{array}$ & $3 \mathrm{kHz}$ & $3 \mathrm{kHz}$ & $3 \mathrm{kHz}$ \\
\hline V & 5 & 7 & 9 \\
\hline Voltage THD (\%) & 239.8 & 238.5 & 239.8 \\
\hline
\end{tabular}

\section{CONCLUSIONS}

This paper presents comparison of symmetrical, binary asymmetrical and ternary asymmetrical CHB-MLI with two H-bridges in series. MATLAB/Simulink models are developed for all the three topologies. Using PD-PWM a pulse generation circuit is designed. From simulation results it is observed that the generated voltage spectrum is very much improved for nine level inverter topology. Among three configurations ternary- CHB inverter requires least number of switches and dc sources and generates high quality voltage with minimum harmonics.

\section{REFERENCES}

[1] J. Rodriguez, J-S. Lai, and F. Z. Peng, "Multilevel inverters: A survey of topologies, controls, and applications," IEEE Trans. Industrial Electronics, Vol. 49, No. 4, pp.724-738, Aug. 2002.

[2] L. G. Franquelo, J. Rodriguez, J. I. Leon, S. Kouro, R. Portillo, and M. A. M. Prats, "The 
age of multilevel converters arrives," IEEE Industrial Electronics Mag., Vol. 2, No. 2, pp. 28-39, Jun. 2008.

[3] L. M. Tolbert, F. Z. Peng, and T. G. Habetler, "Multilevel converters for large electric drives," IEEE Trans. Ind. Appl., Vol. 35, No. 1, pp. 36-44, Jan./Feb. 1999.

[4] M. Malinowski, K. Gopakumar, J. Rodriguez, and M. A. Pérez, "A survey on cascaded multilevel inverters," IEEE Trans. Ind. Electron., vol. 57,no. 7, pp. 2197-2206, Jul. 2010.

[5] S. Kouro, M. Malinowski, K. Gopakumar, J. Pou, L. Franquelo, B. Wu,J. Rodriguez, M. Perez, and J. Leon, "Recent advances and industrial applications of multilevel converters," IEEE Trans. Ind. Electron., vol. 57,no. 8, pp. 2553-2580, Aug. 2010.

[6] H. Abu-Rub, J. Holtz, and J. Rodriguez, "Medium-voltage multilevel converters-State of the art, challenges, and requirements in industrial applications," IEEE Trans. Ind. Electron., vol. 57, no. 8, pp. 2581-2596,Aug. 2010

[7] A.Nabae, I. Takahashi, H.Akagi, "A new neutral-point clamped PWM inverter," IEEE Trans. Ind. App. vol. IA-17, No.5, pp 518-52, Sept/Oct. 1981.

[8] T. A. Meynard, H. Foch, "Multilevel conversion: High voltage choppers and voltage source inverters," IEEE-PESC Conference Record, , pp.397-403,1992.

[9] F. Z. Peng and J. S. Lai, "Multilevel cascade voltage-source inverter with separate DC source," U.S. Patent 5642 275, June 24, 1997.

[10] Farid Khoucha et al," A comparison of symmetrical and asymmetrical three-phase H-bridge multilevel inverter for DTC induction motor drives," IEEE Trans. on Energy Conversion, vol.. 26, no. 1, Mar.2011

[11] Juan Dixon, Javier Pereda "Asymmetrical multilevel inverter for traction drives using only one de supply" IEEE Trans. On Vehicular Technology, vol. 59, no. 8, October 2010 .

[12] Brendan Peter McGrath, Donald Grahame Holmes, "Multicarrier PWM strategies for multilevel inverters" IEEE Trans. On Ind.1 Electronics, vol. 49, no. 4, 2002

International Journal of Engineering Research and Applications (IJERA) is UGC approved Journal with S1. No. 4525, Journal no. 47088. Indexed in Cross Ref, Index Copernicus (ICV 80.82), NASA, Ads, Researcher Id Thomson Reuters, DOAJ.

Aparna Prayag. "Performance Evaluation of Symmetrical and Asymmetrical Cascaded H Bridge Multilevel Inverter Topology ." International Journal of Engineering Research and Applications (IJERA) 7.7 (2017): 20-24. 